\title{
Utilization Of Information And Communication Technology Media In Learning Class V Science In Al Irsyad Al Islamiyyah 02 Purwokerto Academic Year 2019/2020
}

\author{
Farah Hilmy Dwijayanti \\ \{hilmy.fd@gmail.com\} \\ Muhammadiyah University Purwokerto, Central Java, Indonesia
}

\begin{abstract}
The development and use of Information and Communication Technology in education can make reform for a better education system. Especially at the elementary school level learning media is very important so that the knowledge obtained is more concrete. This paper conveys the result of research with a qualitative descriptive approach regarding the form of the use of Information and Communication Technology media in learning Natural Sciences. The location of this study was conducted at Al Irsyad Al Islamiyyah Elementary School 02 Purwokerto, Jatiwinangun, East Purwokerto, Banyumas Regency, Central Java, Indonesia. Data collection techniques used are observation, interviews, and documentation. Data analysis techniques werw performed using the three-step Miles and Huberman model, namely data reduction, data display, and drawing conclusions (conclusing drawing and verification).
\end{abstract}

Keyword : Information Technology, Communication, Science Learning.

\section{Introduction}

Education is a conscious effort made by humans to improve their living standards and become a better human being, both in terms of knowledge and attitude. Education is the first step to one's success. Education does not only provide knowledge but education can shape attitudes towards students, as stated in the Law of the Republic of Indonesia number 20 of 2003 Article 3 concerning the National Education System states that:

"National Education functions to develop capabilities and shape the nation's character and civilization with dignity in order to educate the life of the nation, aiming at developing the potential of students to become human beings of faith and to fear God Almighty, have noble, healthy, knowledgeable, capable, creative, independent , and be a democratic and responsible citizen ".

The law above states that education can not be separated from the formation of attitudes for students to become better. Learning in schools is not only about knowledge, but the formation of attitudes in students becomes important for a school. In the 2013 curriculum there is also the formation of attitudes in students. 
Through the learning process there will be a change or increase in the abilities, knowledge, and skills of students both in terms of cognitive, affective and psychomotor. The learning process must occur optimally at all levels of education, especially elementary school levels as the initial foundation for all students so that this foundation needs enormous strength [17].

Factors that influence the realization of a quality learning process in an effort to achieve educational goals, one of which is the use or utilization of technology in the education and learning process [20]. The learning technology used today is the use of information and communication technology processes and products to solve educational and learning problems, has many benefits or advantages [11]. By utilizing the advantages of learning technology, appropriate and optimal utilization strategies can be formulated in the learning process. The development of technology and communication goes so fast, reaching all sectors of life. In fact, the development is estimated to be faster than originally estimated. In addition, the rapid development of science and technology needs to be balanced with fast and precise motion learning.

The learning media used are very important in achieving the expected results. In other words, the presence of learning media is very helpful in achieving learning goals. Computerbased learning media, or it can be called computer-assisted learning (Conputer Asisted Intructional / CAI), is one of the learning media that is very interesting and is able to increase the learning motivation of students. The use of computers as a learning medium for students' learning motivation. Learning does not depend on having internet access [19].

Another purpose of using learning media can also be obtained from the capabilities of the media itself. ICT as a learning medium, for example, has the following advantages. As a computer media that has multimedia functions (sound, visual, color, writing, symbols, or other information symbols).

Suggests that the use of instructional media in the teaching and learning process can arouse new desires and interests, arouse motivation and stimulation of learning activities, and even bring psychological influences on students [2].

Education at the elementary / MI level is a childhood which lasts from the age of around 6 years to 12 years. During this school age, children are ready to explore the surrounding environment. Curiosity about the environment, how he can be part of the environment he can use simple logic in solving problems. The tendency of this age is to move from concrete things, to see everything as a whole, integrated and then develop following the stages of intellectual, psychological, and motor development [6]

Science as one of the subjects in elementary schools will have a very important role. IPA made a positive contribution. The role of science in education includes 1) being able to increase students' sensitivity to the environment, 2) being able to help students to practice solving problems in their lives related to the surrounding environment. Seeing the importance of science education, it requires a good teacher in teaching the concept of science to children, especially students at the elementary school level [9].

It should also be noted that one of the lessons that students require active learning is the Natural Sciences (IPA). Active learning is a very important factor in supporting the success of students in obtaining optimal learning outcomes. But in reality there are still many students who are passive in following the learning process. This of course becomes a challenge for teachers to create a learning environment that is not boring. Because students who are passive will have the potential to decrease learning outcomes.

Based on these data the researchers conducted a deeper study of Information and Communication Technology in science learning by using a qualitative descriptive approach in primary schools that were ready in terms of providing school facilities and infrastructure using 
the Information and Communication Technology (ICT) media. As well as having a strong vision and background in the use of ICT, this school believes that: (1) This media is believed to be able to help both teachers and students in the learning process, so that the material delivered can be more interesting, creative, active, enthusiastic and enjoyable. (2) In accordance with the vision and mission of the school in improving the quality of schools, the school organizes ICT media as a means of learning media. (3) The use of this media is expected to help the process of learning activities in schools.

\section{Literature Review}

\subsection{Learning Media for Information and Communication Technology (ICT)}

\section{a) Learning Media}

The word media comes from the Latin language and is a plural form of the word medium which literally means an intermediary or introduction. Media is everything that can be used to channel messages from the sender to the recipient so that they can stimulate the thoughts, feelings, concerns and interests of students in such a way that the learning process takes place $[1]$.

Learning media is everything that can convey or channel messages from a source in a planned manner, so that a conducive learning environment occurs where the recipient can carry out the learning process efficiently and effectively [3].

It can be concluded that learning media is an intermediary tool used by teachers in delivering material to students that aims to facilitate the learning process with attractive designs to streamline a learning for the achievement of learning objectives in school.

\section{b) Information and Commucation Technology Media}

Information and Communication Technology (ICT) includes two aspects, namely aspects of Information Technology and aspects of Communication Technology. The difference between Information Technology (IT) and Information and Communication Technology (ICT) is simply stated [7], namely "IT as the technology is used for managed information and ICT as the technology is used to manage information and aid communication". Information and Communication Technology (ICT) as part of Science and Technology (IPTEK) in general are all technologies related to the collection, collection (acquisition), processing, storage, dissemination and presentation of information [13].

In the context of learning, [15] the use of computers is emphasized indeed emphasized, but ICT does not mean limited to the use of sophisticated electronic devices (sophisticated), such as the use of computers and the internet, but also includes conventional tools, such as : printed materials, audio cassettes, Overhead Transparent (OHT) / Overhead Projector (OHP), sound slides, radio, and television.

Another understanding of technology in the context of classroom learning is as a tool or means used to make improvements / improvements to learning activities so that students become more autonomous and critical in dealing with problems, which ultimately lead to an increase in student learning outcomes. Technology can and truly helps students develop all types of skills, ranging from very basic levels to higher levels of thinking skills. [7]. Thus it can be understood that the use of ICT-based learning media can improve student representation abilities. In representation theory, it is explained that by using technology-based learning media, it will facilitate the learning process so that it improves the quality of learning 
and can improve student representation abilities. All technologies relate to the collection, acquisition (acquisition), processing, storage, dissemination and presentation of information.

\section{c) Science Learning}

Natural science is the translation of English words, namely natural stienc, meaning natural science (IPA). Associated with nature or related to nature, while sience means science, so natural science (IPA) or sience can be called science of nature. Science that studies the events that occur in nature. Science is also based on an empirical approach with the assumption that the universe can be studied, understood, and explained which does not depend solely on quality methods but through certain processes, such as observation, experimentation, and rational analysis. In this case certain attitudes are also used, for example trying to act as objectively as possible, and being honest in gathering and evaluating data. The use of scientific processes and attitudes will give birth to new discoveries that become products of science. Science is also based on an empirical approach with the assumption that the universe can be studied, understood, and explained which does not depend solely on quality methods but through certain processes, such as observation, experimentation, and rational analysis. In this case certain attitudes are also used, for example trying to act as objectively as possible, and being honest in gathering and evaluating data. The use of scientific processes and attitudes will give birth to new discoveries that become products of science [5].

IPA as a process is a way of working, a way of thinking and ways of solving a problem, which includes activities of collecting data, linking facts to one another, interpreting data and drawing conclusions [4]. Good science learning must link sanis with students' daily lives. Students are given the opportunity to ask questions, generate student ideas, build curiosity about everything in their environment, build the skills needed, and raise student awareness that learning science is very necessary to learn [18].

The scope of science learning in elementary schools in the 2013 curriculum is adjusted to the level of student needs and improvement in learning outcomes that refer to spiritual aspects, attitudes, knowledge, and skills. The scope of natural science subjects at the elementary level based on the decision is as circular [12].

The scope of subject matter in elementary science includes the body and the five senses, plants and animals, the nature and appearance of surrounding objects, the universe and their appearance, the external shape of the body of animals and plants, the life cycle of living things, the breeding of plants, the form of objects, styles and motion, forms and sources of energy and alternative energy, the shape of the earth and its changes, the environment, the universe, and natural resources, climate and weather, the framework and organs of human and animal bodies, food, food chains, and the balance of ecosystems, the breeding of living things, adaptation of living things to the environment, health and human respiration system, changes and properties of objects, conductance of heat, electricity and magnetism, solar system, mixtures and solutions.

The conclusion of learning in elementary school consists of the concept of the universe, events that occur in the universe, biological concepts, physical concepts, and chemical concepts that are developed conceptually and simply. Some of the scope is part of the basic presentation of science learning materials developed in elementary schools. 


\section{Method}

The study was conducted using a qualitative approach in order to dig deeper information about the use of information and communication technology in science learning. Qualitative research is a research method used to examine the condition of natural objects, and researchers as a key instrument [16]. The type of research used is case study research to find out in-depth facts and find facts about the use of information and communication technology in science learning. Explains a case study is a detailed qualitative research model about an individual or a detailed qualitative research model about a particular individual or social unit over a certain period of time. This study uses data triangulation. In this study, the technique used to check the validity of the data / data validity was the triangulation of data sources [10].

The interviews in this study were the principal of Ustad Agus Tardian, M.Pd and a class V teacher, namely Ustadzah Yuli Setioningrum, S.Si. The location of this research was conducted at Al Irsyad Al Islamiyyah Elementary School 02 Purwokerto, Jatiwinangun Street, Arjuna Gang No.06 Jatiwinangun Purwokerto Lor, East Purwokerto District, Banyumas Regency, Central Java 53114.

The data collection technique used in qualitative research is direct observation to the research object, the researcher observes the facts about the implementation of the use of information technology in science learning and in-depth interviews. Researchers get information directly from the principal and teachers about the use of technology and information in science learning and documentation.

The stage in data analysis that the researcher did was analyzing the data using three steps. The steps are as follows [4]: (1) data reduction: data reduction is a process of selecting, focusing on simplifying, abstracting, and transforming "rough" data that emerge from written records at the research location. This data reduction takes place continuously during qualitative-oriented research activities, (2) presenting data (data display) : The presentation of the data here is a compiled set of information that provides the possibility of drawing conclusions and taking action, (3) drawing conclusions or verification : in this third process the researcher begins to look for objects, noting regularities, patterns, explanations, possible configurations of causal paths, and propositions.

\section{Result And Discussion}

The results of interviews with class V teachers, namely Ustadzah Yuli Setioningrum, S.Si, stated that in the past, manual learning often caused boredom, the solution to improving student learning outcomes was the use of ICT learning. The use of ICT media in science learning at SD Al Irsyad Al Islamiyyah 02 Purwokerto is more than once in the even semester of the 2019/2020 academic year, namely the types of media used are various, namely using power point presentations, learning CDs, google classrooms, google forms, and quizzes . The following is an explanation of the media:

a. Power Point Presentation

The power point percentage is done in the classroom using LCD media and projectors. In the presentation of this power point the material is packaged as attractive as possible, not much writing, lots of pictures and aims. The source of the contents of this power point is obtained from various literatures and modified by the supporting teacher.

b. Learning CD 
This Learning CD displays science learning materials that are packaged attractively. In this learning $\mathrm{CD}$ there are various kinds of animations that make students more enthusiastic in learning.

c. Google Classroom

Google classroom is an application provided by Play Store and can also be accessed on a PC. This Google classroom is an online class so information, instructions, discussion forums, delivery of material, assignments, and daily assessments are done online. The materials in this science learning uploaded to Google classroom can be in the form of learning videos, material summaries in the form of pdfs, and power point slides.

d. Google Forms

Google this form is a tool provided by Google that is used for data filling, surveys and quizzes. In science learning is used for daily evaluation and assessment. So for daily evaluation and assessment using online.

e. Quizizz

Quizizz is an application provided by Playstrore. Quizizz is used to create interactive quiz games for use in classroom learning. Its use is very easy, interactive quizzes that are made have up to 5 answer choices including correct answers. Quizizz can add images to the back screen of questions and adjust the knowledge of the question as desired.

The use of various ICT media is collaborated. So that in the even semester of natural science learning at SD Al Irsyad Al Islamiyah 02 Purwokerto not only uses one ICT media. Especially during the Covid-19 pandemic in mid-March to the end of the semester most of the learning activities used Google classroom, Google forms and qiuzizz.

The media used to adjust the material being taught. If you need a learning video, a video will be provided. However, if only literacy is provided, only a summary / material in the form of pdf. This can be interpreted that every teacher must be observant in the accuracy of choosing ICT media in science learning.

The atmosphere of natural science learning when using ICT media makes children interested, enthusiastic and enthusiastic, especially in using the quizizz application. The quizizz application provides some practice questions whose purpose is to find out the students' abilities after learning. The practice questions given are very different when children work using paper using the quizizz application. In the quizizz application the practice questions are packaged as a challenge (chalangge) so that the child will be more interested in getting the maximum score.

\section{Conclusions}

Based on the results of research and discussion that the author has elaborated on the use of Information and Communication Technology (ICT) media in learning Natural Sciences Class $\mathrm{V}$ at Al Irsyad Al Islamiyyah 02 Purwokerto, Banyuman Regency, Central Java, it can be concluded as follows:

a. Al Irsyad Al Islamiyyah Elementary School 02 Purwokerto is a school institution that is ready in terms of providing school facilities and infrastructure using the Information and Communication Technology (ICT) media. The factors underlying the use of Information and Communication Technology (ICT) media at SD Al Irsyad Al Islamiyyah 02 Purwokerto include (1) This media is believed to be able to help both 
teachers and students in the process of learning activities, so that the material delivered can be more interesting, creative, active, enthusiastic and fun. (2) In accordance with the vision and mission of the school in improving the quality of schools, the school organizes ICT media as a means of learning media. (3) The use of this media is expected to help the process of learning activities in schools.

b. Supporting Factors of the use of Information and Communication Technology media in science learning. Supporting Factors, namely (1) ICT Media at SD Al Irsyad Al Islamiyyah 02 Purwokerto is quite complete. (2) The electricity and internet networks are quite stable. While the inhibiting factors are (1) Limited school rules about not bringing mobile phones to school, (2) there are damaged ICT media and (3) not all teachers are able to master ICT media optimally.

c. The atmosphere of ICT learning in Class V science learning is fun Students are very enthusiastic and like when they are learning. This is evidenced by their always active, happy and excited, especially when using the quizizz application. In using this quizizz, all students are challenged to get the highest score. If more and more students try to achieve the highest score, the more students learn the material.

\section{Reference}

[1] Arief S, Sadiman, (et al). 2010. Educational Media. Jakarta: Raja Grapindo Persada.

[2] Arsyad, Azhar. 2011. Learning Media. Jakarta: Rajawali Press.

[3] Asyhar, Rayanda. 2012. Creative Developing Learning Media. Jakarta: Gaung Persada (GP) Press Jakarta.

[4] Asy'ari, Maslichah. 2006. Application of Science Technology Community Approaches in Learning Science in Primary Schools. Yogyakarta: Sanata Darma University.

[5] Bundu, Patta (2006). Assessment of Process Skills and Scientific Attitudes in Science Learning in Elementary Schools. Jakarta: Ministry of National Education.

[6] Daryanto 2014. Thematic, Integrated, Integrated Learning (2013 Curriculum). Yogyakarta: Gava Media.

[7] Elston, Carol. 2007. Using ICT in the Primary School, Sage Publication.

[8] Fahyuni, Eni Fariyatul. 2017. Technology, Information and Communication. Sidoarjo: Umsida Press

[9] Fatona, Siti and Zuhdan. 2014. Science Learning. Yogyakarta: Ombak.

[10] Herdiansyah, Haris. 2010. Qualitative Research Methods For Social Sciences. Jakarta : Salemba Humanika.

[11] Herman Dwi Surjono. 2010. Utilization of Information and Communication Technology in Improving Learning Quality. Paper, presented at the MGMP Integrated Junior High School / MTs seminar in Magelang City.

[12] Ministry of Education and Culture. 2014. Permendikbud Number 103 of 2014 concerning Evaluation of Learning Outcomes by Educators in Primary and Secondary Education. Jakarta: Indonesian Ministry of Education and Culture.

[13] State Ministry of Research and Technology. 2006. White paper. Research on Development and Application of Science and Technology in Information and Communication Technology 2005 2025. Jakarta: State Ministry of Research and Technology.

[14] Miles, M.B, Huberman, A.M, \& Saldana, J. 2014. Qualitative Data Analysis, A Method Source Book, Edition 3, USA: Usage Publications. Translation of Tjetjep Rohindi Rohidi, UI-Press

[15] Sudirman Siahaan. 2010. Utilization of Information and Communication Technology in Learning. Jakarta: Pustekkomdiknas. 
[16] Sugiyono 2013. Educational Research Methods Quantitative, Qualitative, and R\&D Approaches. Bandung: Alfabeta.

[17] Syaiful Sagala. 2010. Integrated Learning Model. Jakarta: PT. Earth Literacy.

[18] Usman Samatowa. 2006. How about science in elementary schools. Jakarta: Ministry of National Education.

[19] Warsita, Bambang. 2008. Platform Learning Technology and Its Applications. Jakarta: PT Rineka Cipta.

[20] Yusufhadi, Miarso. 2004. Sowing the Seeds of Educational Technology. Jakarta: Prenada Media 